\title{
On Being Accountable in a Kaleidoscopic World
}

Edith Brown Weiss

Georgetown University Law Center, weiss@law.georgetown.edu

abridges 50 Indian J. Intl L. 165-182 (2010)

This paper can be downloaded free of charge from:

https://scholarship.law.georgetown.edu/facpub/1624

http://ssrn.com/abstract=2734401

104 Am. Soc'y. Intl. L. Proc. 477-490 (2010)

This open-access article is brought to you by the Georgetown Law Library. Posted with permission of the author. Follow this and additional works at: https://scholarship.law.georgetown.edu/facpub

Part of the International Humanitarian Law Commons, and the International Law Commons 


\section{MANLEY O. HUDSON MEDAL LECTURE}

The lecture began at 4:15 p.m., Friday, March 26, and was given by Edith Brown Weiss, of Georgetown University Law Center.

\section{On Being Accountable in a Kaleidoscopic World*}

\section{By Edith Brown Weiss}

It is a great honor and pleasure to deliver the Manley $\mathrm{O}$. Hudson Lecture to this distinguished audience of colleagues and friends from across the world. In this presentation, I want to explore the concept of accountability in the changing world in which international law operates, and to draw upon my own recent experience chairing the Inspection Panel at the World Bank. In doing so, I want especially to recognize the concerns of poor people and bring their plight into the discussion of accountability.

The world today differs sharply from that when the United Nations was formed, some 65 years ago. In that world, there were only 51 states, ${ }^{1}$ few international organizations, a nascent global civil society, only 2 billion people, ${ }^{2}$ many of whom lived under colonialism and in poverty, an emerging recognition of human rights, and the glimmerings of globalization. International environmental law, for the most part, did not exist.

Today we have 6.8 billion people, ${ }^{3} 192$ states, ${ }^{4}$ nearly 30,000 active international organizations and another 30,000 inactive ones, ${ }^{5}$ many transnational networks, innumerable corporations that produce globally, and a thriving, networked civil society. Many of our problems are inherently global, such as climate change, health and disease, and financial stability. Poverty is one of the most pressing problems. More than 1.4 billion people exist on less than $\$ 1.25$ per day, and another 1.2 billion people exist on less than $\$ 2.00$ per day. ${ }^{6}$

\section{The KaLeidoscopic WORLD ${ }^{7}$}

International law has developed in the context of states, and, more recently, via transnational actors and networks. In contrast, the context for international law today can be represented by a kaleidoscope. The dictionary defines kaleidoscope, a Greek word in origin, as "a continually shifting pattern, scene, or the likes." 8 (I have a lovely Japanese kaleidoscopic with me, for those who may not be familiar with a kaleidoscope, and an electronic one is on the large screens.) The kaleidoscopic dimension of the international system is informal. The actors and coalitions are constantly changing. Developments are often rapid, as in the financial crisis in late 2008 and 2009, and often unforeseen. International institutions may be established informally rather than by treaty, as, for example, the Financial Stability Board. ${ }^{9}$

\footnotetext{
* A slightly modified version of this address appeared at 50 INDIAN J. INT'L L. 165 (2010).

${ }^{1}$ United Nations, Growth in United Nations Membership, 1945-present, http://www.un.org/en/members/ growth.shtml.

${ }^{2}$ U.S. Census Bureau, Historical Estimates of World Population, http://www.census.gov/ipc/www/worldhis.html.

${ }^{3}$ U.S. Census Bureau, International Database, http://www.census.gov/ipc/www/idb/wordpopinfo.

${ }^{4}$ United Nations, supra note 1.

${ }^{5} 6$ Union of InTERNational Organizations, Yearbook of International Organizations 2008-2009 (7th ed. 2008).

${ }^{6}$ World Bank, World Development Indicators 2008: Poverty Data Supplement 1-2 (2008).

${ }^{7}$ Edith Brown Weiss, International Law in a Kaleidoscopic World, 1 ASIAN J. INT'L L. 21-32 (2011).

${ }^{8}$ Oxford Pocket Dictionary of CuRrent English (2009).

${ }^{9}$ Financial Stability Board, at http://www.financialstabilityboard.org/.
} 
And legal instruments may be non-binding to address new problems that emerge and need immediate attention. This more complicated world offers both challenges and opportunities for the development and implementation of international law.

David Held has written about cosmopolitan multilateralism, in which there are multiple forms of citizenship, anchored in clear and general rules and principles. ${ }^{10}$ In a kaleidoscopic world, states continue to be important, but there are many different informal citizenships, and the anchors are not as solid or clear.

Information technology facilitates the rise in the power of informal groups, ad hoc coalitions and associations, and individuals. Coalitions can form instantaneously on the Internet, and dissolve as quickly. Many advocacy campaigns now take place on Internet sites that allow users to collaborate across time and place, such as Facebook, YouTube, blogs, and Twitter. Mobile phones help in organizing instant coalitions. Some of these campaigns translate into direct action, including the "Pink Chaddi" campaign in Bangalore, ${ }^{11}$ which was started with Facebook, or the high-profile protests in London against alleged indiscriminate shelling of Tamil civilians in Sri Lanka, ${ }^{12}$ which was started with Facebook and mobile texting, and the Internet campaign in the United States for equal pay for men and women. ${ }^{13}$ Within 72 hours, a small coalition in the western United States was able to organize 300,000 phone calls to Congress on a climate bill. ${ }^{14}$ There are many other international examples, including the campaign to ban land mines, ${ }^{15}$ and the so-called color and velvet revolutions in Ukraine and other parts of Central and Eastern Europe. ${ }^{16}$

Blogs have become important means for communicating ideas and influencing others, both locally and globally. As of October 2009, the blog search engine Technorati had tracked more than 133 million blogs. ${ }^{17}$ Three hundred forty-six million people globally read blogs published in 81 different languages, and 900,000 unique blog posts are generated in an average 24-hour period. ${ }^{18}$ The use of Twitter is also increasing. ${ }^{19}$ As of May 2009, the number of unique users of Twitter was reported to be 19.7 million. ${ }^{20}$ During the 2008 attacks in Mumbai, eyewitnesses reportedly sent 80 tweets every five seconds as the tragedy unfolded. ${ }^{21}$

\footnotetext{
${ }^{10}$ See generally CoSmopolitan Democracy: An Agenda for a New World Order (Daniele Archibugi \& David Held eds., 1995).

${ }^{11}$ Pink Chaddis Still Keep Coming In, Trmes (India), Feb. 13, 2009, available at http://timesofindia.indiatimes.com/ Bangalore/Pink_chaddis_still_keep_coming_in_/articleshow/4121276.cms.

${ }^{12}$ Luke Baker, Tamils Block London to Protest Sri Lanka Fighting, ReUTERs, Apr. 20, 2009, http://www.reuters.com/article/idUSLK719456.

${ }^{13}$ See, e.g., WAGE Project, at http://www.wageproject.org/.

${ }^{14}$ Sam Parry, 72 Hour Campaign Generates 300,000 Calls, Envtl. Def. Fund Blog, Mar. 15, 2010, http:// blogs.edf.org/climate411/2010/03/15/72-hour-campaign-generates-300000-calls/.

${ }^{15}$ Jesuit Communications-East Asia and Oceania (JESCOMEAO), The JRS Campaign to Ban Landmines (Mar. 1998).

${ }^{16}$ Mikuláš Teich, Carpatho-Ukraine, the "Velvet Revolution," and the October Revolution, 42 Hist. J. 116978 (1999).

${ }^{17}$ State of the Blogosphere 2009, TECHNORATI, http://technorati.com/blogging/feature/state-of-the-blogosphere2009/.

${ }^{18}$ Adam Singer, Social Media, Web 2.0 and Internet Stats, The Future Buzz, http://thefuturebuzz.com/2009/ 01/12/social-media-web-20-internet-numbers-stats/.

${ }^{19}$ Paul Koch, Supposedly Dismal Twitter Statistics Actually Indicate Strength, VIGET ENGAGE (June 18, 2009), http://www.viget.com/engage/supposedly-dismal-twitter-statistics-actually-indicate-strength.

${ }^{20}$ Id.

${ }^{21}$ Twitter Provided a Vital Link in Mumbai Terrorist Attacks, IMPACT LAB (Nov. 28, 2008), http://www.impactlab.com/2008/11/28/twitter-provided-a-vital-link-in-mumbai-terrorist-attacks/.
} 
Some governments have also begun to use blogs and Twitter. These include China, the European Union, Iran, the United Kingdom, and the United States. ${ }^{22}$ The president of the European Union, for example, maintains a blog to inform people about developments and issues arising in the Union. ${ }^{23}$

While most people do not yet have access to communications technology, access is rising sharply. This is especially true for cell phones, where the rates of access in Africa and in South and Southeast Asia, for example, have risen dramatically, especially during the last few years. ${ }^{24}$ Greater access to communications technology makes it easier for individuals and groups (both formal and informal) to influence the development, interpretation, and implementation of international law.

These developments may be characterized as "bottom-up empowerment." If taken to the fullest extent, this empowerment could mean the democratization of the world. In practice, the scenario unfolding in several parts of the world is a tug of war between government authorities who want to control access and those users of the technology who figure out ways to outsmart whatever controls are put on access, or between groups of users who try to outsmart each other. ${ }^{25}$ Some governments are marshaling the tools as a means to monitor and squelch communications among dissident movements.

This stage in the evolution of the international system is kaleidoscopic. More than ever, international law will need to be viewed as legitimate, both in the eyes of those who create and implement international law, and in the eyes of those affected by it. Being accountable is a key aspect of being legitimate.

\section{ACCOUNTABILITY IN INTERNATIONAL LAW}

In French, the word "responsibilité" includes a concept of accountability. An actor has certain responsibilities that are defined as positive legal rules, which if breached, may trigger certain consequences.

In the English language, the distinction is often made between the responsibility or obligation, and the accountability of the actor for carrying out the obligation. My remarks focus on the latter-the "accountability" aspect-and suggest that we will need a new legal paradigm for considering accountability in the context of a kaleidoscopic world.

Since the term "accountability" has sensitive political connotations, some colleagues may be wary of focusing on it. Moreover, if one has not had a role in developing the international standards for which one will be held accountable, then being accountable can be seen as inflicting yet another inequity in the international legal system. In discussing accountability, the trans-civilizational context offered by Y. Onuma in his lectures at the Hague Academy of International Law ${ }^{26}$ is relevant. This context is based on the plurality of civilizations in which cultural or civilizational assumptions are considered as changeable and functional

\footnotetext{
${ }^{22}$ E.g., Blogs from the U.S. Government, USA.Gov, http://www.usa.gov/Topics/Reference_Shelf/News/ blog.shtml.

${ }^{23} \mathrm{Http}: / / \mathrm{se} 2009$. wordpress.com/.

${ }^{24}$ Ethan Zuckerman, Mobile Phones and Social Activism, TEchSouP (June 20, 2007), http://www.techsoup.org/ learningcenter/hardware/page7216.cfm.

${ }^{25}$ See generally Internet Censorship in China, N.Y. Times, Mar. 23, 2010, available at http://topics.nytimes.com/ topics/news/international/countriesandterritories/china/internet_censorship/index.html; Thomas Erdbrink \& Kay Armin Serjoie, Iran Blocking Foreign, Domestic Web Sites to Curb Anti-Government Activists, Wash. Post, March 10, 2010, available at http://www.washingtonpost.com/wp-dyn/content/article/2010/03/09/AR2010030903478.html.

${ }^{26}$ Yasuaki Onuma, A Trans-Civilizational Perspective of International Law: Lectures in Public International Law at the Hague Academy of Intermational Law, July 30-August 3, 2007, available at http://www.ppl.nV/summercourses/ readinglist.php?year=2007\&lecturer=onuma\&maintopic=Public\%20International\%20Law.
} 
variants. The development and implementation of accountability must be sensitive to the historical context of international law and to the diverse cultures in our world.

Traditionally, international law has addressed the need for accountability through the doctrine of state responsibility. The International Law Commission's 2001 Articles on State Responsibility for Internationally Wrongful Acts $^{27}$ implicitly addresses accountability by states to other states on the basis of positive international legal rules and the consequences from breaching them. The International Law Commission is now using a conceptual framework for international organizations that is similar to that used for state responsibility. ${ }^{28}$

While the work of the International Law Commission on State Responsibility is excellent, in the new kaleidoscopic world the concept of accountability in international law needs to be viewed through a broader and more encompassing lens. I call this the kaleidoscopic lens on accountability. In addition to the changing array of individuals, informal coalitions, and ad hoc groups that we have earlier identified, there is also a burgeoning and changing menu of soft-law norms, informal standards and good practices, and informal institutions established in response to rapid changes.

The work by Brunnée, Curtin, Nollkaemper, and other authors in the 2005 Netherlands Yearbook of International Law recognized that we need a broader conception of accountability than that provided by state responsibility. ${ }^{29}$ Both the International Law Association's 2004 Berlin Conference Report, Accountability of International Organisations, ${ }^{30}$ and the United Kingdom's One World Trust 2006 Global Accountability Report, which covered selected international institutions, multinational corporations, and international nongovernmental organizations, ${ }^{31}$ look toward a more expansive view of accountability.

How do we define accountability? Webster's dictionary defines accountable as "being obliged to account for one's actions, i.e. to give satisfactory reasons." 32 A number of scholars use the term to mean that there are actors who can hold other actors to certain legal rules or standards, to judge whether they have fulfilled their responsibilities in light of these standards, and to impose sanctions if they have not met their responsibilities. ${ }^{33}$ Unless there is accountability, an actor could be responsible for taking certain measures but not have to account to anyone for what is done, and not be subject to any sanctions or other measures. Accountability adds an element of "process" to the theory of legitimacy.

There are a number of conceptual questions that emerge from the international legal and political science literature. Does accountability always operate after the fact, namely, by explaining actions, judging them, and sanctioning them? Or can it include learning and

\footnotetext{
${ }^{27}$ UN Int'1 Law Comm'n, Responsibility of States for Internationally Wrongful Acts, G.A. Res. 56/83, annex, UN Doc. A/56/49(Vol. I)/Corr. 4 (Dec. 12, 2001), available at http://untreaty.un.org/ilc/texts/instruments/english/ draft\%20articles/9_6_2001.pdf.

${ }^{28}$ Report of the International Law Commission on the Work of its Sixty-First Session (4 May-5 June and 6 July-7 August 2009), UN Doc. A/64/10, available at http://untreaty.un.org/ilc/reports/2009/2009report.htm.

${ }^{29}$ See generally Jutta Brunnée, International Legal Accountability Through the Lens of the Law of State Responsibility, 36 NeTH. Y.B. INT'L L. 21-56 (2005); Deirdre Curtin \& André Nollkaemper, Conceptualizing Accountability in International and European Law, 36 NETH. Y.B. INT'L L. 3-20 (2005).

${ }^{30}$ Int'l Law Ass'n, Berlin Conference (2004): Accountability of International Organisations, available at http:// www.ila-hq.org/en/committees/index.cfm/cid/9.

${ }^{31}$ Monica Blagescu \& Robert Lloyd, ONe World Trust: Global accountability Report (2006).

32 See Merriam-Webster OnLine Dictionary, http://www.merriam-webster.com/dictionary/accountable. Webster's New International Dictionary of the English Language (unabridged) in 1946 defined accountable as " answerable'" (at 16).

${ }^{33}$ See, e.g., Robert O. Keohane, The Concept of Accountability in World Politics and the Use of Force, 24 MICH. J. INT'L L. 1121-41 (2003).
} 
preventive components to improve performance? Does accountability always require sanctions? Or does the literature on compliance offer useful guidance on strengthening accountability? (The literature indicates that the intent and capacity of the actors are key variables and suggests that a suite of compliance strategies involving sunshine or transparency, incentives, and capacity-building, as well as sanctions, be available for use, depending upon an actor's intent and capacity. ${ }^{34}$ ) Does accountability in international law apply only between states and intergovernmental institutions, or can it extend to NGOs, corporate networks, and other actors?

In considering these issues, it is useful to look briefly at some of the relevant scholarship on accountability, which offers different models of accountability. Jacobson and Ku distinguished between democratic and non-democratic forms of accountability in their book, Democratic Accountability and the Use of Force in International Law. ${ }^{35}$ Others have articulated diverse models that are consistent with democratic accountability. Political scientists Grant and Keohane distinguished between "participation" and "delegation" models of accountability. ${ }^{36}$ In the participation model, people with power ought to be accountable to those who are affected by their decisions. ${ }^{37}$ In the delegation model, people with power ought to be accountable to those who have entrusted them with it, and to be held to the authority granted or to refrain from acting in violation of its purposes. ${ }^{38}$

Distinctions have also been made between internal accountability (within an organization) and external accountability (to those outside the institution), ${ }^{39}$ or between top-down accountability (managers demanding accountability from employees) and bottom-up accountability (actors being accountable to those affected by their actions, and those affected having a role in making them accountable). ${ }^{40}$ In the context of NGOs, Ebrahim has criticized an "audit culture" model of accountability in favor of a system of reflective accountability, which is aligned with the organization's mission and which focuses on organizational learning and development in response to the needs of clients and communities. ${ }^{41}$

There are at least six questions associated with accountability: Who is accountable? To whom? For what? When? How? And with what consequences? The answers to these questions are multifaceted, context-specific, and sometimes culturally dependent. We shall return to them after considering the work of the World Bank Inspection Panel and the relevance of its work to accountability in the new kaleidoscopic world.

\footnotetext{
${ }^{34}$ Engaging Countries: Strengthening Compliance with International Environmental accords (Edith Brown Weiss \& Harold K. Jacobson eds., 2000).

${ }^{35}$ Democratic Accountability and the Use of Force in International, Law (Charlotte Ku \& Harold K. Jacobson eds., 2003).

${ }^{36}$ Ruth W. Grant \& Robert O. Keohane, Accountability and Abuses of Power in World Politics, 99 AM. PoL. SCI. REv. 29-43 (2005).

${ }^{37}$ Id.

${ }^{38}$ Id.

${ }^{39}$ Peter G. Danchin, Whose Public? Which Law? Mapping the Internal External Distinction in International Law, in Sanctions, Accountability and Governance IN a Globalized World (Kim Rubenstein \& Jeremy Farrell eds., 2009), available at http://digitalcommons.law.umaryland.edu/cgi/viewcontent.cgi?article=1755\&context=fac_pubs.

${ }^{40}$ Edith Brown Weiss, Bottom Up Accountability, 37 Envtl. Pol'y \& L. 259 (2007).

${ }^{41}$ Alnoor Ebrahim, Towards a Reflexive Accountability in NGOs, in Global Accountabilities: ParTicipation, Pluralism, AND Public Ethics 193-223 (A. Ebrahim \& E. Weisband eds., 2007).
} 


\section{ACCOUNTABILITY OF INTERNATIONAL FINANCIAL INSTITUTIONS: The World Bank INSPECTION PANEL}

The World Bank Group in FY 2009 committed $\$ 58.8$ billion in loans, grants, equity investments, and guarantees, a $54 \%$ increase over FY 2008, to combat poverty and promote economic growth. ${ }^{42}$ The Bank has a set of policies and procedures that function like international administrative law to help ensure that its projects and programs, which may be among the most important in the country, promote sustainable economic development. ${ }^{43}$ Questions arise as to whether the World Bank and the other multilateral development banks are effective in their mission and whether they are accountable for meeting their responsibilities.

In 1993 the World Bank Board of Executive Directors established an independent Inspection Panel in response to complaints from countries (especially the U.S. Congress) that Bank projects were causing harm and that a "culture of approval" for proposed projects had developed which did not pay enough attention to whether it satisfied Bank policies and procedures. ${ }^{44}$ The Board of Executive Directors now holds World Bank management and staff accountable for following its policies and procedures by having an independent Inspection Panel receive complaints from poor communities anywhere in the world who believe that they are being harmed, or could be harmed, by a World Bank-financed project or program, including structural adjustment and development policy lending, because the Bank has not followed its policies and procedures. The policies most frequently raised are those concerning environmental assessment, project supervision, involuntary resettlement, indigenous peoples, disclosure of information, poverty reduction, natural habitats, and economic evaluation, in that order. ${ }^{45}$

It is useful to examine the Panel in depth because of the insights it offers into one kind of accountability, namely that it involves the people targeted by the World Bank's mission. The Panel has spurred the development of accountability mechanisms in the other multilateral development banks and in at least three national export or investment agencies. $^{46}$

\footnotetext{
${ }^{42}$ World Bank Inspection Panel, Accountability at the World Bank: The Inspection Panel at 15 Years (2009), available at $\mathrm{http} / / /$ siteresources.worldbank.org/EXTINSPECTIONPANEL/Resources/380793-1254158345788/InspectionPanel2009.pdf (last visited Mar. 20, 2010).

${ }^{43}$ For example, the World Bank policies and procedures include the following: World Bank Operational Policy and Bank Procedure for Physical Cultural Resources, OP/BP 4.11 (2006); World Bank Operational Policy and Bank Procedure for Indigenous Peoples, OP/BP 4.10 (2005); World Bank Procedure on Country Assistance Strategies, BP 2.11 (2005); World Bank Operational Policy and Bank Procedure for Forests, OP/BP 4.36 (2002); World Bank Operational Policy and Bank Procedure for Project Supervision, OP/BP 13.05 (2001); World Bank Operational Policy and Bank Procedure for Projects on International Waterways, OP/BP 7.50 (2001); World Bank Operational Policy and Bank Procedure for Natural Habitats, OP/BP 4.04 (2001); World Bank Operational Policy and Bank Procedure for Involuntary Settlement, OP/BP 4.12 (2001); World Bank Operational Policy for Environmental Action Plans, OP 4.02 (2000, rev. 2002); World Bank Operational Policy for Water Resource Management, OP/BP 4.07 (2000); World Bank Operational Policy and Bank Procedure for Economic Evaluation of Investment Operations, OP/BP 10.04 (1994). For further information on World Bank policies and procedures, see World Bank Operations Manual, http://go.worldbank.org/DZDZ9038D0 (last visited Feb. 19, 2010).

${ }^{44}$ Ibrahim F. I. Shihata, The World Bank Inspection Panel: In Practice (2000) (“' "approval culture' [where] less attention has been given to the commitment of borrowers and their implementing agencies, or to the degree of 'ownership' assumed by borrowers of the projects financed by the Bank and the policies underlying them"); see also LoRi Udall, The World BanK InSPection Panel: A Three-Year Review (1997) (stressing the role of NGOs working with influential members of the U.S. House of Representatives who threatened to withhold U.S. contributions to the tenth replenishment of IDA resources if the Inspection Panel was not created).

${ }^{45}$ World Bank Inspection Panel, Annual Report: July 1, 2006 to June 30, 2007, at 13 (2007), available at http:// siteresources.worldbank.org/EXTINSPECTIONPANEL/Resources/InspP_2007_Annual_Report.pdf.
} 
My four years chairing the Inspection Panel have given me a unique perspective on the operation of accountability in the field. My focus in this presentation is on listening to affected people, who are often very poor, as a way to make those who make decisions affecting them accountable. One can view this as an example of bottom-up accountability. ${ }^{47}$ This accountability is an aspect of the new kaleidoscopic world because it involves individuals, communities and local NGOs, who may have heard about the Panel from many different sources, including the Internet. These actors thus play a key role in ensuring the accountability of a powerful and important inter-governmental organization. I was honored and humbled to have a chance to listen to these poor people in the field.

\section{The Inspection Panel Operations ${ }^{48}$}

A few words about the Panel. It is an independent body within the World Bank Group and reports solely to the Board, and not to Bank management and staff. It hires its own staff. Panel members are selected for one five-year, nonrenewable term and cannot work for the World Bank again.

When the Panel receives a complaint (Request for Inspection), the Panel registers it, and management issues a detailed response within twenty-one days. The Panel then determines whether to recommend an investigation to the Board of Directors, which the Board must approve on a non-objection basis. ${ }^{49}$ Before affected people approach the Panel, they must have raised the problem with Bank staff, an analogy in international law to "exhausting local remedies." Those who make the request can ask that their names be kept confidential, which has happened a number of times. People fear retribution, and the Panel goes to great efforts both at the Bank and in the field to make sure that their identities are protected.

If the Panel investigates, it gathers the relevant expertise, reviews pertinent Bank records, interviews staff, identifies and examines relevant material, and visits the site and meets with affected people, national and local officials, and relevant organizations both in civil society and in the private sector. The Panel then issues a report to the Board, which is a detailed factual analysis and may include important "observations." Within six weeks, Bank management must respond to the Panel's findings and offer an Action Plan for remedying any findings that it has not complied with Bank policies and procedures. The Board of Directors

\footnotetext{
${ }^{46}$ Asian Development Bank [ADB], Review of the Inspection Function: Establishment of a New ADB Accountability Mechanism (2003), available at http://www.adb.org/Documents/Policies/ADB_Accountability_Mechanism/default.asp?p=policies; African Development Bank, African Development Fund, Board of Directors, Independent Review Mechanism, Res. B/BD/2004/9 - F/BD/2004/7 (2004), available at http://www.afdb.org/en/about-us/structure/independent-review-mechanism; European Bank for Reconstruction and Development [EBRD], The Independent Recourse Mechanism, BDS 03-33 (2003), available at http://www.ebrd.com/about/integrity/irm/about/index.htm; EBRD, Project Complaint Mechanism, approved by the Board of Executive Directors, May 6, 2009, available at http://www.ebrd.com/oppor/ngo/am/PCM.pdf; EBRD, Project Complaint Mechanism: Rules of Procedure, May 6, 2009, available at http://www.ebrd.com/about/integrity/irm/about/pcm.pdf; Inter-American Development Bank [IDB], Policy Establishing the Independent Consultation and Investigation Mechanism, Feb. 17, 2010, available at http://idbdocs.iadb.org/wsdocs/getdocument.aspx?docnum=35074768; International Finance Corporation Compliance Advisor/Ombudsman, Operational Guidelines (2007), available at http://www.cao-ombudsman.org/html-english/about.htm; Japan Bank for International Cooperation, Major Rules for Establishment of Examiner for Environmental Guidelines (2009), available at http://www.jbic.go.jp/en/about/environment/guideline/disagree; Overseas Private Investment Corporation, Office of Accountability, available at http://www.opic.gov/doingbusiness/accountability/index.asp; Export Development Canada, Resolutions Respecting the Compliance Officer for Export Development Canada (2001), available at http://www.edc.ca/english/compliance.htm.

${ }^{47}$ Brown Weiss, supra note 40 , at 259.

${ }^{48}$ See International Bank for Reconstruction [IBRD] Res. 93-10 (Sept. 22, 1993); International Developmental Association [IDA] Res. 93-6 (Sept. 22, 1993).

${ }^{49}$ World Bank Executive Directors, 1999 Clarification of the Board's Second Review of the Inspection Panel (Apr. 20, 1999), paras. 7-9.
} 
then considers the Panel's Investigation Report and management's Response and Action Plan and decides what actions need to be taken. In my experience, the Board has always approved management's Action Plan, but sometimes has asked for significant additional measures. ${ }^{50}$

The process is transparent. The Request (or complaint), all of the Panel reports, both eligibility and investigation reports, and management Responses and Actions Plans are available on the Panel's website (www.inspectionpanel.org), and can be read by anyone worldwide with access to the web. In more recent years, the Panel's report has been translated into the major local language so that it can be disseminated and more easily read in the country. Since 2003, the Panel has routinely returned to the Requesters to convey the results of the Inspection Panel investigation, answer questions, and meet with other interested parties in the country, including the highest-level government officials. ${ }^{51}$ That is not always easy if the Panel has validated the Bank's actions. The people may have a terrible problem, but the Bank may not be responsible. Even this is important for poor people to know, so that they can seek the root of the problem in the appropriate place.

While the Panel does not formally monitor what happens afterwards, the Board has sometimes asked the Panel to report back on whether Bank management is implementing the Action Plan prepared in response to the Panel findings. The affected people then continue to be involved. This happened, for example, after the Panel's Yacyretá investigation, ${ }^{52}$ which responded to a complaint from communities in and near Encarnación, Paraguay, involving a $65 \mathrm{~km}$-long dam between Argentina and Paraguay, and after the Panel's Investigation Report on the Mumbai Urban Transport and Infrastructure Project. ${ }^{53}$

Since its beginning, the Inspection Panel has received over 64 Requests (as of March 15, 2010) from 32 geographically diverse countries. ${ }^{54}$ (There were 11 Requests in calendar year 2009). ${ }^{55}$ About a third of the requests are resolved after the complaint is filed, and generally after the Panel's eligibility visit. When poor people file a complaint with the Panel, the highlevel management in the Bank suddenly pays closer attention to the project or program. And things begin to happen.

\section{Selected Panel Requests}

The results of several recent Panel investigations provide insights into the Panel's effectiveness.

\footnotetext{
${ }^{50}$ E.g., World Bank Inspection Panel, Argentina: SEGBA V Power Distribution Project, Paraguay: Reform Project for the Water and Telecommunications Sectors, Inspection Panel Review of Management Progress Report on Implementation of the Management Recommendations and Action Plan, and Additional Implementation Measures, Report No. 31521 (Feb. 7, 2005), paras. 57-66, available at http://siteresources.worldbank.org/EXTINSPECTION PANEL/Resources/PanelReportinspSecm2005-0001.pdf.

${ }^{51}$ World Bank Inspection Panel, Investigation Report for Paraguay-Reform Project for the Water and Telecommunications Sector (Loan No. 3842-PA), Argentina-SEGBA V Power Distribution Project (Loan 2854-AR), Report No. 27995 (Feb. 24, 2004), available at http://siteresources.worldbank.org/EXTINSPECTIONPANEL/Resources/ FullInvestigationReport.pdf; see also World Bank Inspection Panel, Annual Report: July 1, 2003 to June 30, 2004 (2004), available at http://siteresources.worldbank.org/EXTINSPECTIONPANEL/Resources/Annual Report20032004.pdf.

${ }^{52}$ World Bank Inspection Panel, Investigation Report for Paraguay, supra note 51.

${ }^{53}$ World Bank Inspection Panel, Investigation Report for India: Mumbai Urban Transport Project, Report No. 34725 (Dec. 21, 2005), available at http://siteresources.worldbank.org/EXTINSPECTIONPANEL/Resources/ IPNMUTPFINAL.pdf.

${ }^{54}$ World Bank Inspection Panel, supra note 42.

${ }^{55}$ Id.
} 
On August 30, 2007, the Panel conveyed to the Board of Directors its Investigation Report in response to a request from a network of pygmies representing local communities in six provinces across the Democratic Republic of Congo (DRC) ${ }^{56}$ There are several hundred thousand pygmies in DRC, and they have consistently been at the bottom of the social ladder, facing discrimination not only politically but also economically and socially.

The pygmies claimed that they have been harmed, or would be harmed, by the implementation of a new commercial forest concession system that would review existing logging concessions and convert those validated as legal into 25-year titles to engage in industrial logging. DRC is about the size of western Europe and contains about 134 million hectares of forest. These forests, together with the forests in neighboring countries, form the Central African Rain Forest, which is the second largest tropical forest in the world after the Amazon. ${ }^{57}$ The forests have world-class biodiversity value and are home to many endangered species of fauna. Many of the leases under review in DRC were acquired during the moratorium on logging, or had been issued as "swaps" for forested areas that had already been logged or cleared, thus providing for new leases to log during the moratorium.

The Panel found that the Bank had erred in indicating that there were no indigenous peoples in the forests, and hence no need to consider their needs and interests. The Panel also took issue with the Bank's determination that there were no significant environmental or social effects of this forest component in development-policy lending, and hence no need for an environmental assessment. The Panel further found that there was a lack of meaningful participation by pygmy peoples and local communities in the concession reform process and in pilot zoning. Most importantly, the Panel noted that when the Bank initially became engaged in DRC and decided to support work in the forest sector, the Bank provided estimates of export revenue from logging concessions that turned out to be much too high. This encouraged a focus on reform of the concessions at the expense of pursuing sustainable use of forests and exploring the potential for community forests, and conservation. For the most part, foreign companies or local companies controlled by foreigners have been the beneficiaries of this focus. Those whose concessions are confirmed in the review process will be the beneficiaries of new 25-year leases. The Panel also found evidence that the promised benefits to the communities from the forest concessions, such as schools, clinics, and other facilities, have not materialized, which is not consistent with the Bank's policy of reducing poverty. ${ }^{58}$

After the Panel's Report and management's Response and Action Plan, there have been a number of important developments, although the difficulties of development in DRC remain. The Bank has reportedly modified its approach for determining whether there are indigenous people in the Africa region who will be affected by Bank-financed projects and programs; pygmies were given representation on the national commission reviewing the concessions (although under conditions that made it hard for them to participate effectively); there was more consultation with affected communities; efforts have been made with other donors to strengthen monitoring of the forests; and pygmy representatives were invited to an important international conference on forests in Brussels. It is in the interest of DRC to ensure that it has sustainable economic development.

\footnotetext{
${ }^{56}$ World Bank Inspection Panel, Investigation Report: Democratic Republic of Congo: Transitional Support for Economic Recovery Grant and Emergency Economic and Social Reunification Support Project, Report No. 40746ZR (Aug. 31, 2007), available at http://siteresources.worldbank.org/EXTINSPECTIONPANEL/Resources/FINAL INVREPwhole.pdf.

${ }^{57} I d$., Executive Summary, at ix.

${ }^{58}$ Id., para. 533.
} 
The second, earlier investigation concerned the Mumbai Urban Transport Project (MUTP), which is a large-scale, Bank-financed project to expand and improve the rail and road infrastructure in Mumbai. ${ }^{59}$ It involved the resettlement of an estimated 120,000 people. Four different groups of Requesters, totaling more than a thousand people and including shopkeepers along the road as well as residents in nearby neighborhoods, brought a number of claims: that for the shopkeepers along the roads the entitlement to 225 square feet in the resettlement areas regardless of the size of the present structures and nature of the business made it impossible to continue with the businesses; that the baseline surveys of affected people, access to information, and consultations were inadequate; that the location and conditions at the resettlement sites were unsuitable; and that the project failed to consider income restoration-among other concerns.

For its investigation, the Panel followed its usual procedures, including meetings with affected people, government officials, and others, on site visits to the resettlements sites, and interviews with Bank staff. The Panel then produced a detailed technical report of more than 150 single-spaced pages, with many appendices. ${ }^{60}$

The Panel found that the Bank had not complied with its policies and procedures in important respects, particularly with policies on involuntary resettlement and on environmental assessment. The Panel noted that when the Bank made the freestanding resettlement project into a component of the road and rail infrastructure project, the Bank overlooked the needs of the many shopkeepers displaced by road expansion.

Bank management acknowledged the Panel's findings and proposed an Action Plan to bring the Project into compliance, which included expanded options to the shopkeepers for resettlement sites, and improvement in social and environmental services at resettlement sites, such as water supply and sanitation, improved grievance redress measures, and improved databases on affected people. ${ }^{61}$ The Bank suspended disbursement on the road and resettlement components of the MUTP on March 1, 2006-some \$US 80 million-and then lifted the suspension on June 29,2006 , when it concluded that the state of Maharashtra had substantially met the required conditions. ${ }^{62}$

The results for the people are always complicated. The shopkeepers did receive more options, so that a 2,000-square-foot business on a busy road did not have to squeeze into 225 square feet on a lane in a resettlement housing development. The water, sewer, and sanitation facilities at the targeted resettlement site were indeed connected and became operational, although with problems. The grievance procedure was made more independent of the implementing agency.

In a third and more recent request, involving a coastal zone management and clean-up project in Albania, the Panel found that people's homes were demolished in areas covered under the Project, contrary to Bank policies and procedures. Management's Response to the Request had denied that the homes were covered or had been ordered to be demolished. ${ }^{63}$

${ }^{59}$ World Bank Inspection Panel, supra note 53.

${ }^{60} \mathrm{Id}$.

${ }^{61}$ International Bank for Reconstruction and Development, Management Report and Recommendation in Response to the Inspection Panel Investigation Report, India, Mumbai Urban Transport Project, Report No. INSP/R2005005/4 (Feb. 27, 2006), available at $\mathrm{http}$ ://siteresources.worldbank.org/EXTINSPECTIONPANEL/Resources/INDIAManagementResponse.pdf.

${ }^{62}$ World Bank Inspection Panel, supra note 53, paras. 27-30. The Panel appreciated the good working relations with India throughout this investigation.

${ }^{63}$ World Bank Inspection Panel, Investigation Report: Albania: Integrated Coastal Zone Management and Cleanup Project, Report No. 46596-AL (Nov. 24, 2008), paras. 178-217. 
As a result of the Panel's report, the Bank President called for management and staff throughout the Bank to undertake a careful review of the quality and accuracy of their project appraisal documents, in order to be sure that representations in the documents matched the facts on the ground. This is accountability at work.

\section{Reflections on the Panel}

The Inspection Panel aims to be an independent, impartial, and transparent fact-finding body. To the affected people, it is usually a forum of last resort for complaints of harm. For national governments, it is a forum that ensures that Bank-financed projects are taking place according to World Bank policies and procedures, and that can "level the playing field" among countries in the application of Bank policies and procedures. For World Bank management and staff, the Panel is an independent check on their performance and potentially an independent source of validation that they have properly followed Bank policies and procedures. A major effect of the Panel is the "the pre-emptive effect," in the sense that by following their policies and procedures, management and staff hope to pre-empt the need for an investigation, or try to ensure that if one occurs, it will validate the actions of the Bank.

My experience in chairing the Inspection Panel yields certain broader insights into how accountability works in practice.

Fact-finding is valuable as a tool in promoting accountability. Fact-finding provides an impartial way to determine what is or was happening. In response, management must develop its own plan to remedy any findings that faulted the Bank. If the Panel instead were to make recommendations, it would be all too easy to dismiss them, since management and staff may have spent many more hours on the project or program than the Panel. The substance of recommendations can be phrased as observations, which others can pick up as appropriate. By finding facts, rather than making recommendations, it ensures that the Panel does not get co-opted into management. In contrast, if management were to adopt a recommendation by the Panel and something were to go awry, leading to a complaint from affected people, management could argue that the Panel cannot impartially review the complaint and hold management accountable, since it had an operational role in the activity. Fact-finding does not directly carry these risks, since those who are responsible for addressing the findings of the Panel remain responsible for how they address them.

Engaging locally affected people is valuable to the accountability process. Affected people may have important information to convey, both before, during, and after the accountability mechanism acts. During field visits, one can verify the authenticity of those who complain, and ensure that one does not play into a local political agenda. Going to the field makes it possible to see what is really happening. For example, we were assured by the official monitor appointed as part of a forest concession reform project in Cambodia that no illegal logging was taking place, that the largest illegal log would be one carried on a motorcycle. But the next day or so, when we were upcountry, we encountered a large logging truck carrying big logs (a photo appears in the Investigation Report). ${ }^{64}$ In Paraguay, Bank management believed that a drainage system was fully in place at the resettlement site, but when the Panel looked to verify it, it was not. Again, a photo in the field is invaluable evidence. There is no substitute yet for ground truth verification. Consultations with local civil society

\footnotetext{
${ }^{64}$ World Bank Inspection Panel, Investigation Report: Cambodia: Forest Concession Management and Control Pilot Project, Report No. 35556 (Nov. 24, 2008), para. 371.
} 
groups and with the private sector can yield useful insights and help ensure fairness and impartiality in the investigation.

Giving voice to locally affected people is important to effective development. The Panel hears the same story all over the world from powerless people who perceive that they are about to be overwhelmed by a World Bank-financed project or program. In different languages and in different surroundings, the message is the same: we are poor, and what little we have is about to be taken away from us; we are taking our lives in our hands in coming to you, and we do so because we have nothing left to lose and you are our only channel of appeal and our only hope.

This means that it is essential to ensure that there is no retribution, and when there may be, to take action. Many times, we had to make clear to actors at all levels that retribution is, or would be, unacceptable and costly.

Local people were our protection when we went far into hinterlands, in areas that many would consider dangerous. They knew which roadblocks were ahead and how to avoid certain dangers, whether in northern Cambodia, the delta region in Nigeria, or the Sindh in Pakistan.

Earning the respect of all parties is important. The Panel is constantly walking a tightrope between the Board (its nominal boss), the staff of the Bank (at various levels, from task manager to vice-president to the President), the Requesters, the NGO community, and the borrower government of the country where the project is located. It cannot function without their cooperation, yet must call things as it sees them and stand up for its judgments. This demands a reputation for scrupulous fairness and careful technical work.

Gaining the trust of all parties is critical. Trust is essential to effective accountability. In the end, the Panel's effectiveness relies on trust-by Requesters (who are not used to trusting anyone), by governments, by World Bank management and staff, and by civil society. Ensuring transparency of the claims, process, reports, and findings is essential for instilling trust in the system. Transparency allows everyone to identify any mistakes in the findings and to have confidence in them.

An accountability mechanism empowers managers and staff who want to get things right and reveals incompetence or lack of critical resources. Despite the Panel's insistence that it is investigating performance and impacts and not individual responsibility, the attitude of Bank staff toward its work has varied from honest and helpful cooperation to frank stonewalling. The cooperation comes from professional staff who welcome the Panel's examination of their work, sometimes because they believe that their performance will be vindicated, and sometimes because they hope it will uncover misjudgments that they themselves opposed during project preparation or implementation.

It is essential to recognize that effective development entails taking risks. Having a process for holding management and staff accountable minimizes the chance that those harmed will be overlooked. It can also lead to broader acceptance for risky but necessary activities. Some charge that having the Panel results in Panel-proofing projects by omitting important but risky elements. But in my experience that critique may speak to the quality of the project and can be a convenient cover for other things that are wrong with the project.

For accountability to be effective, the system must be able to change in response to the findings of the Panel. Learning must take place. During my tenure on the Panel, management produced "lessons learned" in its Action Plan developed in response to the Panel's findings. In DRC and forest concession reform (industrial logging), the region modified its approach 
for identifying indigenous communities. In response to the Panel's findings on forest concession reform in Cambodia, the Bank altered aspects of its forest policy. In response to the Mumbai Project, the Bank reviewed its risk assessment process, and in response to a Panel report on a project in Albania, the President called for a review of Project Appraisal Documents and other measures to ensure the quality and accuracy of Bank project documents.

Ensuring accountability is not easy. For an institution to be accountable, it is essential to listen to the people who are affected by projects and programs designed to help them. A process for holding management and staff accountable is essential if an institution is to be viewed as legitimate, and if economic development is to be effective.

\section{APPLYING INSIghtS FROM THE FIELD TO ACCOUNTABILITY IN A KaLEIDOSCOPIC WORLD}

Accountability becomes more essential in a kaleidoscopic world-even if it is more difficult-as a means to encourage trust in the system and to foster stability within it.

My experience suggests that accountability is a dynamic process with important feedback loops; that it can occur at any stage of an action-planning, implementation, or post-implementation; that learning from accountability should be an inherent part of the process; and that consequences ensuing as part of accountability must be tailored to the situation and may change over time. The process of accountability is an ongoing process. It is not just retrospective. Rather, it must engage those who are being held accountable at all times.

We return to the six questions posed earlier.

\section{Who Is Accountable?}

In the kaleidoscopic world, all of the actors need to be accountable: states, international organizations, private-sector businesses and networks, NGOs, expert networks, informal groups, ad hoc coalitions, and individuals-when they engage in transnational activities or activities affecting implementation of and compliance with international norms.

\section{To Whom Are They Accountable?}

The Inspection Panel experience suggests that the category of persons and institutions to whom one is accountable needs to be correspondingly broad. One should be accountable not only to those who either established the institution, are its members, or own the institution, but also to those to whom the institutions are expected to serve or are directly or sometimes even indirectly affected by the activities of the institution. Unlike the Inspection Panel, however, it may be difficult to identify the "to whom" in the kaleidoscopic world, since the links may be indirect. To whom are the ad hoc, informal, sometimes instantaneously formed, transnational coalitions accountable? And how does one ensure that accountability to so many actors does not overwhelm what one was trying to do in the first place?

\section{For What Are They Accountable?}

States and international organizations are accountable for complying with certain rules, standards, policies, and practices. But in the rather chaotic and changing kaleidoscopic world, it is not as clear what people are accountable for. This makes fact-finding more difficult as an instrument of accountability because facts must be found in relation to some postulate. It also points to the importance of developing and fostering norms and good practices that 
are embedded in the diverse civilizations of the world and of fostering a widely shared consensus on values. However, we need to be very careful in articulating the "for what," so that we do not discourage taking appropriate risks, stifle innovation, or hamper freedom of speech and assembly.

\section{How Are They Accountable?}

The Panel experience suggests that having the trust of all participants in the process is essential, although difficult. Several elements contribute to trust. For affected people, public participation is essential, especially by those who are adversely affected by what those in power do. They need to have a voice in the process for achieving accountability. Transparency in the process is essential, particularly in the output. In a kaleidoscopic world, where change is rapid, transparency is essential if all the actors are to be able to find out what is happening. Fact-finding is a potentially important means to hold actors accountable, if it is careful, objective, and impartial. It can lead to better accountability, particularly if those to be held accountable are required to address the findings.

\section{When Are They Accountable?}

The Panel experience suggests that it is important to be accountable in preparation for, during, and after the life cycle of the project, program, or other measure. Under this scenario, learning is an important aspect of being accountable. Moreover, with informal ad hoc coalitions that disband quickly, it may be hard to apply accountability only after the fact.

\section{What Are the Consequences for Having Been Held Accountable?}

Here, we need to be very careful in defining the consequences of being held accountable. They may depend on why some actor-whether a state, an international organization or its management or staff, or an individual—did not comply with rules, standards, or good practices. This goes to the two critical variables that affect compliance: intent and capacity. Sometimes intent is a matter of priorities. The strategies to strengthen an actor's accountability-sunshine (transparency, reputation), penalties/sanctions, or incentives (building capacity)—can be matched to these variables. In the kaleidoscopic world, the effects on reputation may be even more important in holding an institution, group, or individual accountable. Also in a kaleidoscopic world, those who hold others accountable may have less control over the consequences than in the past, since there may be consequences beyond what they impose. The New York Times recently featured a story on the "mobs" that can be instantly created. 65 Cultural factors will also be important in designing appropriate consequences. If the relevant society is a consensus society, then we must consider how to ensure accountability in the cultural context of that community.

In conclusion, it is time to take a fresh look at the legal concept of accountability. Accountability is essential to a kaleidoscopic world if we are to promote stability and foster trust among all states and all peoples. But it is also far more difficult. As one step, the International Law Commission, after its work on state responsibility and international organizations, might consider breaking out the legal concept of accountability and addressing it in the broader scope of a kaleidoscopic world.

\footnotetext{
${ }^{65}$ Ian Urbina, Mobs Are Born as Word Grows by Text Message, N.Y. TIMES (Mar. 25, 2010), at A1, available at http://www.nytimes.com/2010/03/25/us/25mobs.html.
} 